\title{
Production and uptake of dissolved carbon, nitrogen, and phosphorus in overlying water of aquaculture shrimp ponds in subtropical estuaries, China
}

Article

Accepted Version

Yang, P., Yang, H., Lai, D. Y. F., Jin, B. and Tong, C. (2019) Production and uptake of dissolved carbon, nitrogen, and phosphorus in overlying water of aquaculture shrimp ponds in subtropical estuaries, China. Environmental Science and Pollution Research, 26. pp. 21565-21578. ISSN 1614-7499 doi: https://doi.org/10.1007/s11356-019-05445-y Available at https://centaur.reading.ac.uk/84093/

It is advisable to refer to the publisher's version if you intend to cite from the work. See Guidance on citing.

To link to this article DOI: http://dx.doi.org/10.1007/s11356-019-05445-y

Publisher: Springer

All outputs in CentAUR are protected by Intellectual Property Rights law, including copyright law. Copyright and IPR is retained by the creators or other copyright holders. Terms and conditions for use of this material are defined in the End User Agreement. 


\section{www.reading.ac.uk/centaur}

\section{CentAUR}

Central Archive at the University of Reading

Reading's research outputs online 
Production and uptake of dissolved carbon, nitrogen and phosphorus in overlying water of aquaculture shrimp ponds in subtropical estuaries, China

Ping Yang ${ }^{1,2,3 *}$, Hong Yang,5,6, Derrick Y.F. Lai ${ }^{7}$, Baoshi Jin ${ }^{1,2}$, Chuan Tong1,2,3*

${ }^{1}$ Key Laboratory of Humid Subtropical Eco-geographical Process of Ministry of Education, Fujian Normal University, Fuzhou 350007, P.R. China

${ }^{2}$ School of Geographical Sciences, Fujian Normal University, Fuzhou 350007, P.R. China

${ }^{3}$ Research Centre of Wetlands in Subtropical Region, Fujian Normal University, Fuzhou 350007, P.R. China

${ }^{4}$ Collaborative Innovation Center of Atmospheric Environment and Equipment Technology, Jiangsu Key Laboratory of Atmospheric Environment Monitoring and Pollution Control (AEMPC), School of Environmental Science and Engineering, Nanjing University of Information Science \& Technology, 219 Ningliu Road, Nanjing 210044, China

${ }^{5}$ College of Environmental Science and Engineering, Fujian Normal University, Fuzhou, 350007, China

${ }^{6}$ Department of Geography and Environmental Science, University of Reading, Whiteknights, Reading, RG6 6AB, UK

${ }^{7}$ Department of Geography and Resource Management, The Chinese University of Hong Kong, Shatin, New Territories, Hong Kong SAR, China

*Correspondence to: Ping Yang

Telephone: 086-0591-87445659

Fax: 086-0591-83465397

Email: yangping528@ sina.cn (P. Yang)

**Correspondence to: Chuan Tong

Telephone: 086-0591-87445659

Fax: 086-0591-83465397

Email: tongch@fjn.edu.cn (C. Tong) 


\begin{abstract}
Water quality deterioration can adversely affect the long-term sustainability of aquaculture industry. Understanding the processes of nutrient regeneration and uptake is important for improving water quality and the overall ecosystem health of aquaculture systems. In spite of the importance of dissolved nutrients (DOC, DIC, $\mathrm{N}-\mathrm{NO}_{\mathrm{x}}{ }^{-}, \mathrm{N}-\mathrm{NH}_{4}{ }^{+}$, and $\mathrm{P}-\mathrm{PO}_{4}{ }^{3-}$ ) in governing water quality and ecosystem functioning, the spatiotemporal variations in the production and uptake of dissolved nutrients in aquaculture ponds is still poorly understood. In this study, the nutrient production and uptake rates in the overlying water were quantified among different shrimp growth stages in the aquaculture ponds in the Min River Estuary (MRE) and Jiulong River Estuary (JRE), southeast China. Significant differences in the nutrient production and uptake rates in the overlying water were observed among the three growth stages and two estuaries. The temporal variations of DOC and DIC production rates in both estuarine ponds closely followed the seasonal cycle of temperature, while the difference in DOC and DIC production rates between the two estuaries was likely caused by differences in water salinity. The changes in the production and uptake rates of dissolved inorganic nitrogen $\left(\mathrm{N}-\mathrm{NO}_{\mathrm{x}}{ }^{-}\right.$and $\left.\mathrm{N}-\mathrm{NH}_{4}{ }^{+}\right)$and $\mathrm{P}_{-} \mathrm{PO}_{4}{ }^{3-}$ in the water column over time were partly related to the interactions between thermal conditions and phytoplankton biomass (e.g., chlorophyll $a$ concentrations) in the ponds. Our results demonstrate the complex dynamics and environmental risk of dissolved nutrients in subtropical shrimp ponds, and call for a more effective management of nutrient-laden wastewater in safeguarding the long-term sustainability of aquaculture production.
\end{abstract}

Keywords Nutrients $\cdot$ Uptake $\cdot$ Production $\cdot$ Overlying water $\cdot$ Aquaculture pond $\cdot$ Subtropical estuary

\title{
Nomenclature table
}

\begin{tabular}{|c|c|c|c|}
\hline Nomenclature & Abbreviations & Nomenclature & Abbreviations \\
\hline Min River Estuary & MRE & $\begin{array}{l}\text { DOC production rates in the } \\
\text { overlying water }\end{array}$ & DOC_prod \\
\hline Jiulong River Estuary & JRE & $\begin{array}{l}\text { DIC production rates in the overlying } \\
\text { water }\end{array}$ & DIC $_{\text {prod }}$ \\
\hline Litopenaeus vannamei & L. vannamei & Dissolved organic carbon & DOC \\
\hline Metric tons & Mt & Dissolved inorganic carbon & DIC \\
\hline Nitrite & $\mathrm{N}-\mathrm{NO}_{2}^{-}$ & Chlorophyll $a$ & Chl- $a$ \\
\hline Nitrate & $\mathrm{N}-\mathrm{NO}_{3}^{-}$ & Dissolved oxygen & DO \\
\hline Ammonium & $\mathrm{N}-\mathrm{NH}_{4}{ }^{+}$ & Dissolved organic matter & DOM \\
\hline Phosphate & P-PO ${ }_{4}^{3-}$ & & \\
\hline
\end{tabular}




\section{Introduction}

As a result of rising living standards, the demand for protein-rich seafood has been growing rapidly in recent years. The production of shrimps, as one of the most favoured seafood, has been on an increasing trend around the world. The global total production of shrimp was about 2.1 million tonnes in the year 2015 (FAO 2016), with prawn (Litopenaeus vannamei) being a highly popular aquaculture product in the Asia-Pacific region. Intensive shrimp aquaculture has been considered to be important in sustaining a steady aquaculture production (FAO 2016; Molnar et al. 2013; Silva et al. 2013). The successful operation of intensive shrimp aquaculture ponds depends on active human management activities, such as the stocking of fries, daily supply of feeds, and others (Chen et al. 2016; Yang et al. 2018). These pond systems receive a large quantity of nutrients from residual feeds and shrimp excreta (Chen et al. 2016), which can subsequently lead to water quality deterioration and harmful algae blooms once nutrient levels in the water column exceed certain thresholds (Huang et al. 2016; Yang et al. 2017). Hence, a thorough understanding of the nutrient dynamics in pond water is critical for assessing the trophic status, primary productivity, yield, and environmental risks of intensive aquaculture shrimp ponds.

The variations of nutrient concentrations in aquatic systems are closely related to the processes of nutrient production and uptake. The production of nutrients in aquatic systems can contribute to a negative feedback (e.g., water quality deterioration, toxics) on the environment through releasing nutrients (e.g., $\mathrm{N}-\mathrm{NO}_{\mathrm{x}}{ }^{-}, \mathrm{N}-\mathrm{NH}_{4}{ }^{+}$and $\mathrm{P}_{-} \mathrm{PO}_{4}{ }^{3-}$ ) into the water column (Holmer et al. 2015). In contrast, nutrient uptake can potentially reduce the ambient nutrient concentrations in water and thereby create a positive feedback on the ecosystem (Holmer et al. 2015). Nutrient regeneration and uptake in natural aquatic ecosystems (e.g. lake, river, and ocean) have received great attention in recent studies (e.g., Bronk et al. 2014; Fernández et al. 2009; Fields et al. 2014; Finkler et al. 2018; McCarthy et al. 2016). Researchers have found that the variations in nutrient regeneration and uptake are associated with phytoplankton biomass (e.g., Fellows et al. 2006; Hall et al. 2003; Hargreaves 1998), hydrology and hydrogeomorphology (e.g., Fields et al. 2014; Gücker and Pusch 2006), carbon availability (e.g., Ensign and Doyle 2006; Yang et al. 2008), and nutrient limitation and availability (e.g., Finkler et al. 2018). Nutrient regeneration and uptake have also been measured in long-line mussel farms and pearl oyster culture systems (e.g., Carlsson et al. 2012;Christensen et al. 2003; Holmer et al. 2015; Jansen et al. 2012; Lacoste and Gaertner-Mazouni 2016; Srisunont and Babel 2015; van Broekhoven et al. 2014). These studies were based on measurement of bivalve (and associated fauna) excretion providing regenerated nutrient to the system. In this kind of studies, empty chambers are used as control and fluxes are generally negligible (e.g. Richard et al. 2007). Studies measured nutrient process using tracers (e.g., $\mathrm{N}^{15}$ isotopes) or addition of nutrients such degradation occurs because sediment accumulate along aquaculture ropes and between bivalves so microbial process take place in the suspended sediment compartment of water. However, the data on nutrient production and uptake of aquaculture ponds is still 
scarce. The biogeochemical cycling of nutrients in aquaculture systems generally involve multiple processes, e.g. nutrient fluxes across the sediment-water interface (SWI), nutrient regeneration and uptake in the water column, nutrient release through animal excretion, etc. However, the potential contribution of nutrient regeneration and uptake in the water column to the biogeochemical cycling of nutrients from the aquaculture systems remains poorly documented.

As an indispensable part of the global aquaculture system, aquaculture ponds are widely distributed in the temperate and tropical regions, in particular in the developing countries. These ponds are generally semi-artificial ecosystems maintenance supported by daily feed supply to culture aquatic animals (Aiméa et al. 2018; Chen et al. 2016; Yang et al. 2018). Consequently, the pond water nutrient dynamics is crucial to the long-term sustainability of the aquaculture industry. While Yang et al. (2017) have estimated the $\mathrm{N}-\mathrm{NO}_{\mathrm{x}}{ }^{-}, \mathrm{N}-\mathrm{NH}_{4}{ }^{+}$and $\mathrm{P}-\mathrm{PO}_{4}{ }^{3-}$ fluxes across the sediment-water interface in the estuarine aquaculture ponds, the process of nutrient production in the water column of aquaculture ponds, particularly in China with the world's largest aquaculture area, is still largely unknown. Moreover, the spatiotemporal variability of the rates of production or uptake of dissolved nutrients in aquaculture ponds is poorly characterized, which could lead to considerable biases in estimating the nutrient fluxes in this ecosystem. Understanding the dynamics of nutrient regeneration and uptake in aquaculture ponds is thus essential for promoting the sustainable development of the aquaculture industry.

China, as the world's leading aquaculture producer, had a total cultivation area of $58,579 \mathrm{~km}^{2}$ (Verdegem and Bosma 2009) and annual production of 29.4 million metric tons (Mt) in 2015 (Fisheries Department of Agriculture Ministry of China 2015). Shrimp pond is one of the major types of aquaculture ponds in China, with a wide distribution along the coastal regions (Yang et al. 2017). This study aims to investigate the nutrient dynamics of shrimp ponds located in two different estuaries in Fujian Province, southeast China. The specific objectives of this study are to: (1) quantify the production and uptake rates of dissolved nutrients among three different growth stages of shrimps; (2) compare the production and uptake rates of dissolved nutrients between two different estuaries; (3) identify the factors influencing the production and uptake of dissolved nutrients in pond water.

\section{Materials and methods}

\section{Study sites}

The study was conducted in two subtropical estuaries, namely Min River Estuary (MRE) and Jiulong River Estuary (JRE), situated in southeast China (Fig. 1). The Min River Estuary has a typical subtropical monsoonal climate with relatively warm and wet weather. The multi-year average temperature and precipitation are $19.6^{\circ} \mathrm{C}$ and 1,350 mm, respectively (Tong et al. 2010). The Jiulong River Estuary has a subtropical 
oceanic climate with multi-year mean air temperature of $21.0^{\circ} \mathrm{C}$ and annual rainfall of $1,371 \mathrm{~mm}$ (Wang et al. 2016). Both estuaries receive significant amount of southeast monsoonal rain between May and September. The two estuaries have semi-diurnal tides with an average range of $4.5 \mathrm{~m}$ and $4.0 \mathrm{~m}$ in the MRE and JRE, respectively. The wetland soil surface is submerged for $7 \mathrm{~h}$ over a $24 \mathrm{~h}$ cycle. The catchment areas of the Min River and Jiulong River are 60,092 and 14,741 $\mathrm{km}^{2}$, respectively, with annual discharge of $58.6 \times 10^{9}$ and $12.4 \times 10^{9} \mathrm{~m}^{3} \mathrm{y}^{-1}$, respectively (Zhou et al. 2016). The mean salinity of tidal water at MRE is $5.1 \pm 2.6 \%$, which is significantly lower than that in JRE (23.6 $\pm 3.2 \%$ ). The shrimp ponds, being one of the dominant landscape features in these estuarine zone, were mostly generated by the complete removal of marsh vegetation.

\section{Shrimp pond system and management}

Aquaculture production in the majority of the shrimp ponds occurs between June and November (Yang et al. 2017a), with only one crop of shrimps being produced per year. Prior to shrimp production, these ponds are filled with estuarine water from an adjacent estuary using a submerged pump. The water is first filtered through a $2 \mathrm{~mm}$ mesh bag in order to prevent the entry of predators and competitors (Guerrero-Galván et al. 1999; Yang et al. 2017a). Additional input of freshwater into the ponds takes place occasionally during rainfall events. There is no water exchange with the spillways of the ponds during the farming period. The water depths in the shrimp ponds at the MRE and JRE range between 1.1 -1.5 m, and 1.3-1.8 m, respectively, with the average values of $1.3 \mathrm{~m}$ and $1.5 \mathrm{~m}$, respectively.

To assess the production and uptake processes of dissolved nutrients in the overlying water during the culture period, water samples were collected from three replicate commercial shrimp ponds in the Shanyutan Wetland of the MRE and Humao Island of the JRE (Fig. 1). The basic details about the selected shrimp ponds can be found in Table S1 in the Supporting Information. The shrimp production cycle began on May 15, 2015, and lasted for about 163 days. Litopenaeus vannamei were fed with artificial feeds containing $42 \%$ of crude protein (Yuehai ${ }^{\mathrm{TM}}$, Guangzhou, China) twice per day at 07:00 and 16:00 (local standard time), respectively, by direct application from a small boat. The shrimp grow-out cycle was divided into three stages (initial, middle, and final stages) according to the management practices (e.g. feeding rate, water depth, etc.), water salinity, and shrimp weight (Table S2), which was similar to the classification scheme adopted by Páez-Osuna et al. (1997) The feeding rates were maintained at approximately 10-16, 50-55, and 40-45 $\mathrm{kg} \mathrm{ha}^{-1} \mathrm{~d}^{-1}$ during the initial, middle, and final stages, respectively. The amount of feed added was determined according to the response of shrimps to the previous feeding. At each pond, three to five $1,500-\mathrm{W}$ paddlewheel aerators were activated four times per day at 07:00-09:00, 12:00-14:00, 18:00-20:00, and 00:00-03:00 (local standard time). Pond water was completely drained and surface sediment $(0-10 \mathrm{~cm})$ was removed after shrimp harvest. 


\section{Collection and analysis of water samples}

Taking into account the shrimp grow-out cycle, the field sampling campaigns were carried out in the middle of June, August, and October of 2015 to represent the three stages. Three replicate sites were chosen in each pond for the sampling of overlying water (approximately 5-10 $\mathrm{cm}$ above the sediment surface). Overlying water was collected during each sampling campaign using a 5 L Niskin bottle, and then immediately transported to the laboratory for the incubation experiment and the measurement of chlorophyll $a$ (chl- $a$ ) concentrations (Zhang et al. 2013). Chl- $a$ concentrations in the water samples were determined using a UV-visible spectrophotometer (Shimadzu UV-2450, Japan) following the methods of Jeffrey and Humphrey (1975) and Yang et al. (2017a). Physico-chemical properties of the overlying water, including temperature, $\mathrm{pH}$, salinity, and dissolved oxygen (DO), were measured in situ simultaneously. The temperature and $\mathrm{pH}$ were determined using a portable $\mathrm{pH} / \mathrm{mV} /$ Temp system (IQ150, IQ Scientific Instruments, USA). Salinity and DO were determined using a salinity meter (Eutech Instruments-Salt6, USA) and a multi-parameter water quality meter (HORIBA, Japan), respectively. All the instruments were calibrated in the laboratory before each field campaign according to the instruction manuals.

\section{Laboratory incubation and analysis of nutrient fluxes}

Triplicate overlying water samples were retrieved from each pond for use in an incubation experiment to examine the production and uptake of nutrients including dissolved organic carbon (DOC), dissolved inorganic carbon (DIC), $\mathrm{N}-\mathrm{NO}_{\mathrm{x}}{ }^{-}\left(\mathrm{N}-\mathrm{NO}_{2}{ }^{-}+\mathrm{N}-\mathrm{NO}_{3}{ }^{-}\right), \mathrm{N}-\mathrm{NH}_{4}{ }^{+}$and $\mathrm{P}-\mathrm{PO}_{4}{ }^{3-}$. The rates of nutrient production and uptake in the overlying water were determined using an ex situ incubation. The incubation device (Fig. S1, Supporting Information) was designed following Chen et al. (2014), Cowan and Boynton (1996), and Xiong et al. (2017). The incubation chambers were constructed using transparent Plexiglas with an internal diameter of $6.0 \mathrm{~cm}$ and a height of $30 \mathrm{~cm}$. In the laboratory, overlying water samples were filtered through a 0.45 $\mu \mathrm{m}$ cellulose acetate filter and transferred into the incubation chambers, while the cores were sealed using a Teflon plunger with inlet and outlet tubes. Before the incubation, the DO concentration in the overlying water was adjusted to achieve the in situ level. We monitored the DO level and introduced air into the water column occasionally to replenish the oxygen consumed, as well as providing mixing of the water column. The chambers were incubated in light in a temperature-regulated incubator (QHZ-98A, China) for $9 \mathrm{~h}$ to simulate the typical conditions experienced during the daytime period. The incubation temperature was selected according to the in situ temperature (MRE: 22.5 (June), 28.5 (August), and 22.5 (October); JRE: 25.5 (June), 29.0 (August), and 26.5 (October)). We recognize that this ex situ incubation would only take into account the biogeochemical processes that take place within the water column, while under actual field conditions, nutrient dynamics in pond water might also be affected by sediment-water interactions as well as faunal activities. 
Approximately $60 \mathrm{~mL}$ of overlying water was withdrawn from each incubation chamber using a $100 \mathrm{~mL}$ plastic syringe at the beginning and the end of the 9-hour incubation period. The water samples were subsequently transferred to $60 \mathrm{~mL}$ polyethylene bottles, and injected with about $0.2 \mathrm{~mL}$ of saturated $\mathrm{HgCl}_{2}$ solution to inhibit microbial activities (Taipale and Sonninen 2009; Zhang et al. 2013). Approximately $30 \mathrm{~mL}$ of water samples were then filtered through a $0.45 \mu \mathrm{m}$ cellulose acetate filter (Biotrans ${ }^{\mathrm{TM}}$ nylon membranes), and the filtrates were stored in $30 \mathrm{~mL}$ polyethylene bottles before the analysis of $\mathrm{N}_{-} \mathrm{NO}_{\mathrm{x}}{ }^{-}\left(\mathrm{N}-\mathrm{NO}_{2}{ }^{-}+\mathrm{N}-\mathrm{NO}_{3}{ }^{-}\right), \mathrm{N}^{-} \mathrm{NH}_{4}{ }^{+}$, and $\mathrm{P}_{-} \mathrm{PO}_{4}{ }^{3-}$ concentrations by a flow injection analyser (Skalar Analytical $\mathrm{SAN}^{++}$, Netherlands). The detection limits for $\mathrm{N}-\mathrm{NO}_{2}{ }^{-}, \mathrm{N}-\mathrm{NO}_{3}{ }^{-}, \mathrm{N}-\mathrm{NH}_{4}{ }^{+}$, and $\mathrm{P}_{-} \mathrm{PO}_{4}{ }^{3-}$ were 0.02 ,

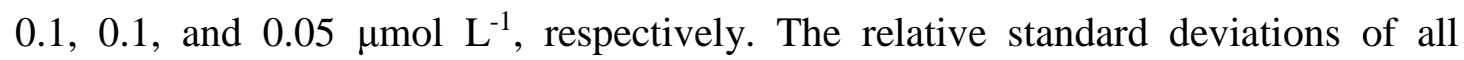
analyses were in the range of $0.1-4.0 \%$. The remaining water samples were also filtered immediately through a $0.45 \mu \mathrm{m}$ cellulose acetate filter (Biotrans ${ }^{\mathrm{TM}}$ nylon membranes) that was pre-combusted at $450{ }^{\circ} \mathrm{C}$ for $4 \mathrm{~h}$, and the filtrates were then stored in $30 \mathrm{~mL}$ pre-combusted glass bottles before the analysis of DOC and DIC concentrations by a total organic carbon analyzer (TOC-VCPH/CPN, Shimadzu, Japan). The detection limits for DOC and DIC were both $0.4 \mu \mathrm{g} \mathrm{\textrm {L } ^ { - 1 }}$. The relative standard deviations of all analyses were in the range of $0.5-3.0 \%$. All samples were stored at $4^{\circ} \mathrm{C}$ in the dark until further analysis.

The production and uptake rates of dissolved nutrients in the overlying water were determined as follows (Cheng et al. 2015; Yang et al. 2017a):

$$
F=\left(C_{W-E}-C_{W-B}\right) \times V / S / T / H
$$

where $F\left(\mathrm{mg} \mathrm{m}^{-3} \mathrm{~h}^{-1}\right)$ is the rate of nutrient production and uptake in the overlying water (positive and negative values indicate a net production and a net uptake, respectively, by the overlying water), $C_{\mathrm{W}-\mathrm{E}}$ and $C_{\mathrm{W}-\mathrm{B}}$ are the nutrient concentrations $\left(\mathrm{mg} \mathrm{L}^{-1}\right)$ in the overlying water at the end and the beginning of incubation, respectively, $V$ is the volume of overlying water (L), $S$ is the cross-sectional area of the incubation tube $\left(\mathrm{m}^{2}\right)$, $T$ is the incubation time (h) and $H$ is the height of the incubation tube (m).

\section{Statistical analyses}

Two-way analysis of variance (ANOVA) was conducted to explore whether aquaculture stages, sampling estuaries or their interaction have fixed effects on environmental variables, the production and uptake of dissolved carbon, nitrogen and phosphorus in overlying water of aquaculture shrimp ponds. Pearson correlation analyses were conducted to examine the relationships between various environmental variables and the production/uptake rates of dissolved nutrients. A stepwise regression analysis was used to identify the major environmental factors governing the temporal variations of dissolved carbon, nitrogen and phosphorus production rates in the overlying water of different estuarine ponds. All statistical analyses were performed using the SPSS statistical software package (SPSS v 17.0, Inc., USA), and were 
considered significant at the 0.05 significance level. All statistical plots were generated using OriginPro 7.5 (OriginLab Corp. USA).

\section{Results and discussions}

\section{Overlying water characteristics}

Table 1 shows the physio-chemical and biological properties of overlying water in the shrimp ponds during the farming period. The temporal patterns of overlying water properties were similar between the two estuaries. Both temperature and Chl- $a$ concentrations in the overlying water decreased in the order of middle stage $>$ final stage > initial stage (Table 1). The overlying water $\mathrm{pH}$ varied significantly among the three growth stages $(p<0.05)$, with considerably lower values observed during the middle stage (Table 1). DO concentrations in the water column showed an increasing trend over time (Table 1), whereas salinity exhibited an opposite trend (Table 1). There were significant differences in DO concentration and salinity among the three stages $(p<0.05)$.

Large variations in overlying water characteristics were also found between the two estuaries. Water temperature and salinity at the JRE ponds were significantly higher than those at the MRE ponds over the study period ( $p<0.01$; Table 1$)$. Mean DO concentration at the JRE ponds was significantly lower than that at the MRE ponds during the middle and final stages ( $p<0.001$; Table 1$)$, while no significant differences were detected during the initial stage $(p>0.05$; Table 1$)$. Overlying water Chl- $a$ concentrations at the JRE ponds were significantly lower than those at the MRE ponds across all three growth stages $(p<0.001$; Table 1$)$. Significant difference in overlying water $\mathrm{pH}$ between the two estuaries was recorded during the initial and final stages ( $p>0.05$; Table 1).

\section{Production of DOC and DIC in the overlying water}

During the production cycle, aquaculture ponds receive daily feed supply and subsequently retain a large amount of organic matter from residual feeds and feces (Chen et al. 2016). Therefore, dissolved / particulate organic matter decomposition in the aerobic water column might be an important contributor to the internal DOC and DIC production (DOC_prod and DIC_prod ) in the shrimp ponds. The results of our laboratory incubation experiment on the DOC and DIC production rates in the overlying water are presented in Fig. 2. The mean DOC_prod rates in the MRE and JRE ponds across the three shrimp growth stages were $277.79 \pm 67.51 \mathrm{mg} \mathrm{m}^{-3} \mathrm{~h}^{-1}$ (range: 162.93-396.64) and 248.08 $\pm 34.15 \mathrm{mg} \mathrm{m}^{-3} \mathrm{~h}^{-1}$ (range: 182.11-296.35) (Fig. 2a). The mean DIC_prod rates in the MRE and JRE ponds were $552.95 \pm 202.08 \mathrm{mg} \mathrm{m}^{-3} \mathrm{~h}^{-1}$ (range: 186.99-884.50) and $316.89 \pm 73.18 \mathrm{mg} \mathrm{m}^{-3} \mathrm{~h}^{-1}$ (range: 186.52-439.66), respectively. The mean DIC_prod rate was significantly higher than that of $\mathrm{DOC}_{-}$prod $(p<0.05)$, showing 
that inorganic carbon species was the major products of dissolved organic matter (DOM) decomposition in the water column of shrimp ponds. A clear temporal pattern of DOC_prod and DIC_prod rates was observed across the three shrimp growth stages in all ponds in the descending order of middle stage $>$ final stage $>$ initial stage (Fig. 2 and Table 2). The temporal variations in DOC_prod and DIC_prod rates were, to a large extent, dependent on the interactions between thermal conditions and other environmental factors (such as organic matter, salinity, $\mathrm{pH}$ and DO) (Table 3 and Table 4). Firstly, the significant and positive relationships observed between water temperature, and the rates of DOC_prod and DIC_prod ( $p<0.01$; Table 3$)$ suggested that temperature was likely an important driver of the temporal changes in the rates of DOC_prod and DIC_prod. An increase in temperature could stimulate the microbial activity in the water column, and subsequently accelerate the decomposition of organic matter (Pinho et al. 2016; Porcal et al. 2015) and the production of DOC and DIC during the middle stage. Secondly, changes in DO concentrations might alter the activity of microorganisms in the water column, which in turn affect the temporal dynamics of DOC_prod and DIC_prod rates in the MRE ponds, as supported by the significant correlations observed between DO concentrations and the rates of DOC_prod, DIC_prod (Table 3). Previous studies have also suggested that microbial mineralization of organic matter under aerobic conditions in the water column plays a key role in governing aquatic carbon cycling (Cory et al. 2014; Wang et al. 2017; Weyhenmeyer et al. 2015; Yang et al. 2015),

Salinity is also an important driver of ecosystem processes in coastal wetlands (Neubauer et al. 2013; Tong et al. 2017). The negative relationships observed between water salinity and both DOC_prod and DIC_prod rates in the current work (Table 3) were consistent with the results reported in several previous studies in tidal wetlands (Craft 2007; Morrissey et al. 2014; Neubauer 2012; Roache et al. 2006). Under increasing salinity, the activity of soil microorganisms and enzymes will be suppressed, resulting in an overall decrease in the rate of microbial decomposition of organic carbon (Chambers et al. 2013; Morrissey et al. 2014; Neubauer 2012). Thus, the significantly lower DOC_prod and DIC_prod rates observed during the initial stage of shrimp growth in this study might be partly related to the significantly higher water salinity, which exerted a negative effect on microbial decomposition of organic matter in the water column. We also found significant differences in DOC_prod and DIC_prod rates between the two estuaries (Table 2), except for DOC_prod in the final stage and DIC_prod in the initial stage (Fig. 2). Over the whole study period, the mean values of DOC_prod and DIC_prod were higher in MRE than JRE ponds $(p<0.001)$, which might be related to the significantly lower average salinity, and higher DO and Chl- $a$ concentrations (Table 1) in the former that promoted organic matter decomposition .

\section{Production and uptake of dissolved inorganic nitrogen in the overlying water}

The results of our laboratory incubation experiment on the production and uptake rates of nitrogen $\left(\mathrm{N}^{-\mathrm{NO}_{x}}{ }^{-}\right.$and $\left.\mathrm{N}-\mathrm{NH}_{4}{ }^{+}\right)$in the overlying water of shrimp ponds are shown in Fig. 3. The average rates of $\mathrm{N}-\mathrm{NO}_{x}{ }^{-}$production and $\mathrm{N}-\mathrm{NH}_{4}{ }^{+}$uptake in MRE ponds were 2.16 $\pm 0.44 \mathrm{mg} \mathrm{m}^{-3} \mathrm{~h}^{-1}$ (range: $1.40-2.92$ ) and $26.65 \pm 10.69 \mathrm{mg} \mathrm{m}^{-3} \mathrm{~h}^{-1}$ (range: 


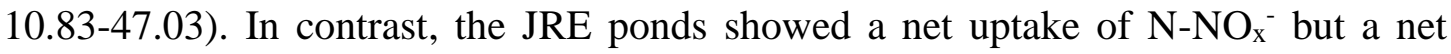
production of $\mathrm{N}_{-\mathrm{NH}_{4}}^{+}$, with mean rates of $1.07 \pm 0.31 \mathrm{mg} \mathrm{m}^{-3} \mathrm{~h}^{-1}$ (range: $0.54-1.63$ ) and $27.31 \pm 12.05 \mathrm{mg} \mathrm{m}^{-3} \mathrm{~h}^{-1}$ (range: 14.02-51.37). The rates of production and uptake of dissolved inorganic nitrogen varied greatly between the two estuaries (Table 5), and exhibited a clear seasonal trend with generally higher values in the middle stage (Fig. 3a and Fig. 3b).

Dissolved organic matter (DOM) and particulate organic matter (POM) is widely existed in almost every species of water bodies, which are rich in biogenic element (e.g., carbon, nitrogen and phosphorus) (e.g., Simon et al. 2002; Yao et al. 2014; Zhu et al. 2019). DOM and POM in the aquatic systems (e.g., lake) is usually derived from the allochthonous input and autochthonous biological degradation (e.g., phytoplankton degradation) (e.g., Simon et al. 2002; Yao et al. 2011, 2014; Zhang et al. 2009; Zhu et al. 2019). The degradation of (DOM) and POM is an important link in the biogeochemical process of nutrients regeneration (Yao et al. 2014). In general, a large supply of DOM and POM provides a reliable source of substrates for the microbial mineralization of nitrogen in water. The middle stage is considered to be the main period for boosting shrimp growth (Yang et al. 2017), during which a large amount of organic matter is introduced through feed inputs and shrimp metabolism, and subsequently dissolved in water (Zhu et al. 2019). The combination of high water temperature and large supply of

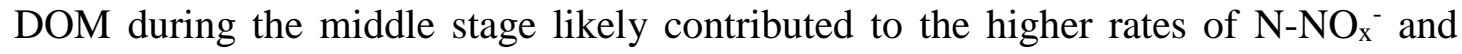
$\mathrm{N}-\mathrm{NH}_{4}{ }^{+}$production observed in the MRE and JRE ponds, respectively, as compared to other stages, as supported by the significant, positive relationships observed between water temperature and $\mathrm{N}^{-} \mathrm{NO}_{\mathrm{x}}{ }^{-}$(MRE ponds) or $\mathrm{N}^{-\mathrm{NH}_{4}}{ }^{+}$(JRE ponds) $(p<0.05$, Tables 4 and 6). More detailed investigations of the DOM and POM in the two estuaries during the culture period are further needed to confirm the above hypothesis.

We observed a net uptake of $\mathrm{N}^{-\mathrm{NH}_{4}}{ }^{+}$and $\mathrm{N}-\mathrm{NO}_{\mathrm{x}}{ }^{-}$in the MRE (Fig. 3a) and JRE ponds (Fig. 3b), respectively, which were probably related to the phytoplankton dynamics (e.g., community composition and biomass). Different phytoplankton species have different physiological abilities to use a given nutrient source (Cunha et al. 2017; Glibert et al. 2006). Blomqvist et al. (1994) found that cyanobacteria and diatoms prefer $\mathrm{N}-\mathrm{NH}_{4}{ }^{+}$and $\mathrm{N}-\mathrm{NO}_{\mathbf{x}}{ }^{-}$, respectively, as a nitrogen source. In general, cyanobacteria are widely distributed in freshwater or low salinity aquatic ecosystems (Paerl et al. 2001), while diatoms live mostly in oceans and other saltwater environments (Armbrust 2009). Due to a lower amount of freshwater input, the annual mean salinity in Jiulong River Estuary was $\sim 5$ times higher than that in Min River Estuary, which in turn led to a significantly higher salinity in the JRE than MRE ponds (6.1-15.1\%o vs. 1.9-3.4\%o) throughout the study period (Yang et al. 2018). Therefore, the net uptake of $\mathrm{N}^{-\mathrm{NO}_{\mathrm{x}}}{ }^{-}$

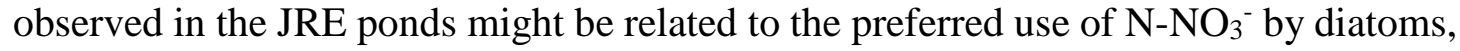
while the net uptake of $\mathrm{N}-\mathrm{NH}_{4}{ }^{+}$observed in the MRE ponds could be linked to the preferred utilization of $\mathrm{N}^{-\mathrm{NH}_{4}}{ }^{+}$as a nitrogen source by cyanobacteria. More detailed investigations of the phytoplankton community in the two estuaries are further needed to confirm the above hypothesis. On the other hand, the strong temporal variability observed in the net uptake rates of $\mathrm{N}^{-\mathrm{NH}_{4}}{ }^{+}$and $\mathrm{N}-\mathrm{NO}_{\mathrm{x}}{ }^{-}$in the estuarine ponds might be related to phytoplankton activities. The significant and positive relationships found 
between Chl- $a$ concentrations and $\mathrm{N}-\mathrm{NH}_{4}{ }^{+} / \mathrm{N}^{-} \mathrm{NO}_{\mathrm{x}}{ }^{-}$uptake rates in the estuarine ponds ( $p<0.01$; Tables 4 and 6) suggested that an increase in phytoplankton biomass could enhance the rate of $\mathrm{N}_{-} \mathrm{NH}_{4}{ }^{+}$and $\mathrm{N}-\mathrm{NO}_{x}{ }^{-}$uptake from the water column, which was consistent with the findings in some tropical reservoirs (e.g., Cunha et al. 2017).

\section{Uptake of dissolved $\mathrm{P}-\mathrm{PO}_{4}{ }^{3-}$ in the overlying water}

The mean uptake rate of $\mathrm{P}-\mathrm{PO}_{4}{ }^{3-}$ in the MRE and JRE ponds over the study period were $3.27 \pm 0.72 \mathrm{mg} \mathrm{m}^{-3} \mathrm{~h}^{-1}$ (range: $2.13-4.60$ ) and $2.18 \pm 0.55 \mathrm{mg} \mathrm{m}^{-3} \mathrm{~h}^{-1}$ (range: $1.38-3.24$ ) (Fig. 3c). The $\mathrm{P}_{-} \mathrm{PO}_{4}{ }^{3-}$ uptake rates in the shrimp ponds of both estuaries varied greatly among the three growth stages, which decreased in the order of middle stage $>$ final stage $>$ initial stage $(p<0.001$; Fig. 3c). Phosphorus uptake in the aquatic systems is driven mostly by the interactions between biotic and abiotic process. Previous studies have reported that phosphorus uptake is governed by primary production (e.g., Fellows et al. 2006; Gücker and Pusch 2006), carbon availability (e.g., Ensign and Doyle 2006; Yang et al. 2008), and nutrient supply (Tromboni et al. 2018). In the present study, the $\mathrm{P}-\mathrm{PO}_{4}{ }^{3-}$ uptake rate was significantly and positively correlated with water temperature $(P<0.001$; Table 6$)$, indicating that thermal energy was an important factor driving the temporal patterns of $\mathrm{P}_{-} \mathrm{PO}_{4}{ }^{3-}$ uptake in the estuarine ponds. The positive effect of temperature on $\mathrm{P}_{-} \mathrm{PO}_{4}{ }^{3-}$ uptake could be related to biological mechanisms (Angelo et al. 1991). A higher temperature can stimulate microbial activity and algal bloom, which in turn would increase the microbial demand for phosphorus and biotic uptake of $\mathrm{P}_{-} \mathrm{PO}_{4}{ }^{3-}$ (Brown and Shilton 2014; Finkler et al. 2018). This hypothesis was supported by the significant and positive relationship found between $\mathrm{P}-\mathrm{PO}_{4}{ }^{3-}$ uptake rate, water temperature, and Chl- $a$ concentrations ( $p<0.001$; Table 6). Moreover, we found that $\mathrm{P}_{-} \mathrm{PO}_{4}{ }^{3-}$ uptake rate was negatively correlated with water $\mathrm{pH}$ in JRE ponds (Table 6). Baldy et al. (2015) have similarly observed a stronger phosphorus uptake in softwater $\left(\mathrm{pH}=7.2\right.$, conductivity $\left.=72 \mu \mathrm{S} \mathrm{cm}^{-1}\right)$ than in hardwater $(\mathrm{pH}=8.4$, conductivity $=669$ $\mu \mathrm{S} \mathrm{cm}{ }^{-1}$ ), especially under nutrient-enriched conditions. This is because under more alkaline conditions, orthophosphates can combine more easily with calcium to form apatite $\left(\mathrm{Ca}_{5}\left(\mathrm{PO}_{4}\right)_{3} \mathrm{OH}\right)$, which is a form of phosphorus unavailable to aquatic organisms (e.g., planktonic algae and aquatic plant) (Baldy et al. 2015; Chambers et al. 2001).

Abiotic $\mathrm{P}$ uptake can occur through sorption processes, which include both adsorption on the surfaces of cationic minerals and precipitation with electrolytes (Finkler et al. 2018; House and Warwick 1999; Reddy et al. 1999). Iron (Fe) and aluminum (Al) can form complexes with organic matter to support P sorption (Finkler et al. 2018; Reddy et al. 1999). Future studies should quantify the metal dynamics and examine their relationship with $\mathrm{P}_{-} \mathrm{PO}_{4}{ }^{3-}$ production/ uptake more explicitly.

The $\mathrm{P}_{-} \mathrm{PO}_{4}{ }^{3-}$ uptake rates in the overlying water of shrimp ponds differed significantly between the two estuaries, with the mean values being 1.5 times higher in the MRE than JRE ponds ( $3.27 \pm 0.72$ vs. $\left.2.18 \pm 0.55 \mathrm{mg} \mathrm{m}^{-3} \mathrm{~h}^{-1}\right)$, which might be related to the significantly lower salinity in the former $(p<0.01$; Table 1$)$. Salinity can induce stress in the coastal ecosystems primarily through its effects on ionic strength and the 
microbial pathway of organic matter mineralization (Chambers et al. 2013; Wang et al. 2015). With an increase in salinity, the competition between various species of anions (e.g. $\mathrm{Cl}^{-}, \mathrm{SO}_{4}{ }^{2-}, \mathrm{HCO}_{3}{ }^{-}, \mathrm{OH}^{-}$and $\mathrm{Br}^{-}$) for the surface adsorption sites would intensify, while at the same time displacing the adsorbed phosphate from the particle surface (Meng et al. 2015; Millero et al. 2001; Zhang and Huang 2011). In addition, we found a significantly higher mean Chl- $a$ concentration in the MRE than JRE ponds $(p<0.01$; Table 1), which could support a higher uptake rate of $\mathrm{P}_{-} \mathrm{PO}_{4}{ }^{3-}$ by phytoplankton as discussed previously.

\section{Role of sediments in the biogeochemical cycling of nutrients in shrimp ponds}

The biogeochemical cycling of nutrients in aquaculture ponds generally involve multiple processes, e.g. nutrient fluxes across the sediment-water interface (SWI), nutrient regeneration and uptake in the water column, nutrient inputs through animal excretion, etc. (Hargreaves 1998). Lacoste and Gaertner-Mazouni (2016) reported that nutrient regeneration by pearl oyster culture in the water column often had the largest contribution to the nutrient concentrations in the water column of aquaculture systems. In our previous study, the average $\mathrm{N}-\mathrm{NO}_{\mathrm{x}}{ }^{-}, \mathrm{N}-\mathrm{NH}_{4}{ }^{+}$and $\mathrm{P}-\mathrm{PO}_{4}{ }^{3-}$ fluxes across the SWI in the Min River estuarine ponds were found to be $0.25 \pm 0.16,41.42 \pm 6.69$, and $2.74 \pm 0.71 \mathrm{mg} \mathrm{m}^{-2} \mathrm{~h}^{-1}$, respectively (Yang et al. 2017). Jiang et al. (2000) and Li et al (2006) reported that the rates of $\mathrm{N}_{-} \mathrm{NO}_{\mathrm{x}}{ }^{-}, \mathrm{N}_{-} \mathrm{NH}_{4}{ }^{+}$and $\mathrm{P}_{-} \mathrm{PO}_{4}{ }^{3-}$ input from shrimp excreta ranged between 1.08-4.32, 31.86-126.72, and 0.69-7.94 $\mathrm{mg} \mathrm{m}^{-2} \mathrm{~h}^{-1}$, respectively. Assuming that these reported rates of shrimp excretion of nutrients were representative of those in the Min River estuarine ponds, the rate of $\mathrm{N}^{-\mathrm{NO}_{\mathrm{x}}}{ }^{-}$flux across the SWI was substantially lower than that produced by either shrimp excretion rates or regeneration in the overlying water. Our results showed that the sediment was likely not the most dominant contributor of $\mathrm{N}-\mathrm{NO}_{\mathrm{x}}{ }^{-}$levels in the water column of MRE ponds. Meanwhile, the sediment might play a more significant role in governing the dissolved $\mathrm{N}_{-} \mathrm{NH}_{4}{ }^{+}$and $\mathrm{P}_{-} \mathrm{PO}_{4}{ }^{3-}$ concentrations in the subtropical estuarine aquaculture ponds, as shown by the significantly higher fluxes of both $\mathrm{N}_{-} \mathrm{NH}_{4}{ }^{+}$and $\mathrm{P}-\mathrm{PO}_{4}{ }^{3-}$ across the SWI as compared to the rates of shrimp excretion and regeneration of these nutrients in the water column.

\section{Implications of dissolved nutrient production in the shrimp pond water}

Shrimp culture has expanded remarkably worldwide, accompanied by increasing concerns about shrimp diseases (Castillo-Soriano et al. 2013; da Silva et al. 2013; Yang et al. 2017). In this study, we observed the emergence of shrimp diseases in the ponds of both estuaries, with a higher rate of shrimp mortality during the middle and late stages. The mean shrimp survival rates in the MRE and JRE ponds were $65 \%$ and $70 \%$, respectively (unpublished data), which were lower than the average level of $80 \%$ reported nationally (Lai 2014). At the meantime, the nutrient production rates (e.g., DOC, DIC and $\mathrm{N}-\mathrm{NO}_{\mathrm{x}}{ }^{-}$) in Min River estuary were higher than those in Jiulong River estuary (Fig. 2 and Fig. 3). Given the similar temporal patterns between the emergence of shrimp diseases and the production rates of dissolved nutrients in both estuaries (Fig. 
2 and Fig. 3), the presence of excessive nutrients in the water column might exert a negative impact on shrimp survival. An increased nutrient level or imbalanced N:P ratios could lead to the attainment of toxic levels of nitrogen (e.g., ammonia and nitrite) and undesirable growth of harmful algae (da Silva et al. 2013; Mook et al. 2012). Sediment release of dissolved nutrients is also a potentially important source of nutrients in supporting harmful algal blooms in the water column (Yang et al. 2017; Zhang et al. 2006). In the present study, the observed high rates of nutrient production in the water column could help satisfy the majority of nutrient requirements for the primary productivity in shrimp ponds, which in turn lead to the formation of harmful algal blooms. We found a net production of $\mathrm{N}^{-\mathrm{NO}_{x}}{ }^{-}$and $\mathrm{N}^{-\mathrm{NH}_{4}}{ }^{+}$in the MRE (Fig. 5a) and JRE ponds (Fig. 5b), respectively, which might have contributed to the emergence of shrimp diseases during the middle and late stages. Moreover, the relatively low rates of shrimp survival in the ponds of both estuaries were probably related to the high production rates of DOC and DIC, as the decomposition of organic matter into dissolved carbon in aquaculture systems would consume a large amount of DO and thus pose a threat to shrimp lives (Mook et al. 2012; Zhang et al. 2016). Given the high nutrient production rate in the water column, this internal biogeochemical process could contribute significantly to dissolved nutrient levels in coastal aquaculture ponds, leading to the degradation of water quality and hampering the long-term sustainability of shrimp production systems. Therefore, it is important to take effective measures to mitigate environmental pollution from aquaculture (Yang 2014; Yang et al. 2015).

\section{Limitations and future research}

This research has a number of limitations, as is the case of many other studies. We used ex situ incubation under controlled conditions to determine the production and uptake rates of nutrients in the overlying water of shrimp ponds. Conducting an in situ experiment in future might be useful to produce results that can better represent the natural variability of environmental parameters experienced under field conditions. Also, researchers have found that the dynamics of DIC and DOC are associated with the activities of microorganisms and enzymes in the water column (Chambers et al. 2013; Morrissey et al. 2014; Neubauer, 2012), which were excluded in the current study and deserve further investigations. Moreover, given the potential importance of $\mathrm{Fe}$ and Al complexes in the dynamics of $\mathrm{P}_{-} \mathrm{PO}_{4}{ }^{-3}$ (Finkler et al. 2018; Reddy et al. 1999), future studies should quantify the metal dynamics and examine their relationship with $\mathrm{P}_{-} \mathrm{PO}_{4}{ }^{3-}$ production more explicitly. Furthermore, the specific role of shrimp excretion in the nutrient dynamics in pond water should be studied in greater detail, since previous studies have shown that the shrimp excretion could be an important contributor to dissolved nutrients (e.g., N-NO${ }_{x}{ }^{-}, \mathrm{N}-\mathrm{NH}_{4}{ }^{+}$and $\mathrm{P}-\mathrm{PO}_{4}{ }^{3-}$ ) in water (Jiang et al. 2000; $\mathrm{Li}$ et al. 2006; Zhong et al. 2015). Lastly, our results were based on field sampling in a limited number of shrimp ponds, and future studies should increase the spatial representativeness by covering a greater number of sites over a larger region in characterizing the nutrient dynamics in shrimp ponds. 


\section{Conclusions}

Owing to rapid expansion of aquaculture production to meet the increasing demand of protein-rich seafood, there is an increasing worldwide concern on the environmental impacts arising from such activities. In the study, the rates of production and uptake of dissolved nutrients in the shrimp ponds of two subtropical estuaries were measured at three different growth stages over the grow-out cycle. The following key findings on the biogeochemical cycling of dissolved nutrients in the aquaculture ponds in the southeastern coast of China were obtained:

1) Large DOC and DIC production rates were observed in the overlying water of shrimp ponds, indicating that the overlying water of shrimp ponds during the culture period of shrimps were "hotspots" of DOC and DIC production.

2) A net uptake of $\mathrm{N}-\mathrm{NH}_{4}{ }^{+}$but a net production of $\mathrm{N}-\mathrm{NO}_{3}{ }^{-}$were found in the overlying water of shrimp ponds in the Min River Estuary, while an opposite pattern was observed for $\mathrm{N}_{-} \mathrm{NH}_{4}{ }^{+}$and $\mathrm{N}_{-} \mathrm{NO}_{3}{ }^{-}$in the Jiulong Min River Estuary, which might be related to the preferential use of different nitrogen forms by phytoplankton species with different physiological abilities between the two estuaries.

3) High rate of $\mathrm{P}_{-} \mathrm{PO}_{4}{ }^{3-}$ uptake was observed in the overlying water of shrimp ponds in both estuaries, implying that phosphorus could potentially become a limiting nutrient for phytoplankton growth in the shrimp ponds.

4) Marked variations in the nutrient production and uptake rates were observed between the two estuaries and among the three shrimp growth stages, indicating a significant spatiotemporal variability of dissolved nutrient dynamics in shrimp ponds.

\section{Acknowledgements}

This research was supported by the National Science Foundation of China (No. 41801070, 41671088), the Research Grants Council of the Hong Kong Special Administrative Region, China (CUHK458913, 14302014, 14305515), the CUHK Direct Grant (SS15481), Open fund by Jiangsu Key Laboratory of Atmospheric Environment Monitoring and Pollution Control (KHK1806), A Project Funded by the Priority Academic Program Development of Jiangsu Higher Education Institutions (PAPD), and Minjiang Scholar Programme. We would like to thank Lishan Tan, Weining Du and Jingyu Zhang of the School of Geographical Sciences, Fujian Normal University, for their field assistance. We sincerely thank the reviewers and editor for their valuable comments.

\section{References}

Aiméa J, Allenbach M, Bourgeois C, Léopold A, Jacotot A, Vinh TV, Nho NT, Patrona LD, Marchand C (2018) Variability of $\mathrm{CO}_{2}$ emissions during the rearing cycle of a semi-intensive shrimp farm in a mangrove coastal zone (New Caledonia). Mar Pollut Bull 129:194-206. https://doi.org/10.1016/j.marpolbul.2018.02.025 
Angelo, ADJD, Webster JR, Benfield EF (1991) Mechanisms of stream phosphorus retention: An experimental study. J N Am Benthol Soc 10:225-237. doi:10.2307/1467596

Armbrust EV (2009) The life of diatoms in the world's oceans. Nature 459(7244):185. doi:10.1038/nature08057

Baldy V, Thiebaut G, Fernandez C, Sagova-Mareckova M, Korboulewsky N, Monnier Y, Perez T, Tremolieres M (2015) Experimental assessment of the water quality influence on the phosphorus uptake of an invasive aquatic plant: biological responses throughout its phenological stage. PLoS ONE 10(3):e0118844. doi:10.1371/journal.pone.0118844

Blomqvist P, Petterssona A, Hyenstrand P (1994) Ammonium nitrogen: A key regulatory factor causing dominance of nonnitrogen-fixing cyanobacteria in aquatic systems. Archiv für Hydrobiologie 132(2):141-164. doi:10.3892/ijmm.2015.2202

Bronk, DA, Killberg-Thoreson L, Sipler RE, Mulholland MR, Roberts QN, Bernhardt PW, Garrett M, O'Neil JM, Heil CA (2014) Nitrogen uptake and regeneration (ammonium regeneration, nitrification and photoproduction) in waters of the West Florida Shelf prone to blooms of Karenia brevis. Harmful Algae 38:50-62. doi:10.1016/j.hal.2014.04.007

Brown N, Shilton A (2014) Luxury uptake of phosphorus by microalgae in waste stabilisation ponds: current understanding and future direction. Rev Environ Sci Biotechnol 13(3):321-328. doi:10.1007/s11157-014-9337-3

Carlsson MS, Engström P, Lindahl O, Ljungqvist L, Petersen JK, Svanberg L, Holmer M (2012) Effects of mussel farms on the benthic nitrogen cycle on the Swedish west coast. Aquacult Environ Interac 2:177-192. doi:10.3354/aei00039

Chambers LG, Osborne TZ, Reddy KR (2013) Effect of salinity-altering pulsing events on soil organic carbon loss along an intertidal wetland gradient: a laboratory experiment. Biogeochemistry 115 (1-3):363-383. doi:10.1007/s10533-013-9841-5

Chambers PA, Prepas EE, Ferguson ME, Serediak M, Guy M, Holst M (2001) The effects of lime addition on aquatic macrophytes in hard water: in situ and microcosm experiments. Freshwater Biol 46(8):1121-1138. doi:10.1046/j.1365-2427.2001.00794.x

Christensen PB, Glud RN, Dalsgaard T, Gillespie P (2003) Impacts of longline mussel farming on oxygen and nitrogen dynamics and biological communities of coastal sediments. Aquaculture 218:567-588. doi:10.1046/j.1365-2427.2001.00794.x

Casillas-Hernández R, Mgallón-Barajas F, Portillo-Clarck G, Páez-Osuna F (2006) Nutrient mass balances in semi-intensive shrimp ponds from Sonora, Mexico using two feeding strategies: trays and mechanical dispersal. Aquaculture 258:289-298. doi:10.1016/j.aquaculture.2006.03.027

Castillo-Soriano FA, Ibarra-Junquera V, Escalante-Minakata P, Mendoza-Cano O, de Jesús Ornelas-Paz J, Almanza-Ramírez JC, Meyer-Willerer AO (2013) Nitrogen dynamics model in zero water exchange, low salinity intensive ponds of white shrimp, Litopenaeus vannamei, at Colima, Mexico. Lat Am J Aquat Res 41(1):68-79. doi:10.3856/vol41-issue1-fulltext-5

Chambers LG, Osborne TZ, Reddy KR (2013) Effect of salinity-altering pulsing events on soil organic carbon loss along an intertidal wetland gradient: a laboratory experiment. Biogeochemistry 115:363-383. doi:10.1007/s10533-013-9841-5

Chen Y, Dong SL, Wang F, Gao QF, Tian XL (2016) Carbon dioxide and methane fluxes from feeding and no-feeding mariculture ponds. Environ Pollut 212:489-497. doi:10.1016/j.envpol.2016.02.039

Chen ZH, Chen NW, Wu YQ, Mo QL, Zhou XP, Lu T, Tian Y (2014) Sediment-water flux and processes of nutrients and gaseous nitrogen release in a China river reservoir. Environ Sci 35(9):3325-3335. (in Chinese)

Cheng XL, Hou LJ, Liu M, Yin GY, Li XF, Li XB, Gao J, Deng FY, Jiang XF (2015) Inorganic nitrogen exchange across the sediment-water interface in the eastern Chongming tidal flat of the Yangtze Estuary. Environ Earth Sci 74(3):2173-2184. doi:10.1007/s12665-015-4207-z 
Cory RM, Ward CP, Crump BC, Kling GW (2014) Sunlight controls water column processing of carbon in arctic fresh waters. Science 345(6199):925-928. doi:10.1126/science.1253119

Cowan JLW, Boynton WR (1996) Sediment-water oxygen and nutrient exchanges along the longitudinal axis of Chesapeake Bay: Seasonal patterns, controlling factors and ecological significance. Estuaries 19(3):562-580. doi:10.2307/1352518

Craft C (2007) Freshwater input structures soil properties, vertical accretion, and nutrient accumulation of Georgia and US tidal marshes. Limnol Oceanogr 52:1220-1230. doi:10.4319/lo.2007.52.3.1220

Cunha DGF, de Melo Lima VF, Néri AM, Marafão GA, Miwa ACP, do Carmo Calijuri M, Bendassoli JA, Tromboni F, Maranger R (2017) Uptake rates of ammonium and nitrate by phytoplankton communities in two eutrophic tropical reservoirs. Int Rev Hydrobiol 102(5-6):125-134. doi:10.1002/iroh.201701900

da Silva KR, Wasielesky Jr. W, Abreu PC (2013) Nitrogen and phosphorus dynamics in the biofloc production of the pacific white shrimp, Litopenaeus vannamei. J World Aquacult Soc 44(1):30-41. doi:10.1111/jwas.12009

Ensign SH, Doyle MW (2006) Nutrient spiraling in streams and river networks. J Geophys Res Biogeosci 111:1-13. doi:10.1029/2005JG000114

FAO (2016) The State of World Fisheries and Aquaculture 2016 Contributing to food security and nutrition for all. Rome, pp200.

Fellows CS, Valett HM, Dahm CN, Mulholland PJ, Thomas SA (2006) Coupling nutrient uptake and energy flow in headwater streams. Ecosystems 9:788-804. doi:10.1007/s10021-006-0005-5

Fernández C, Farías L, Alcaman ME (2009) Primary production and nitrogen regeneration processes in surface waters of the Peruvian upwelling system. Prog Oceanogr 83:159-168.

Fields L, Nixon SW, Oviatt C, Fulweiler RW (2014) Benthic metabolism and nutrient regeneration in hydrographically different regions on the inner continental shelf of Southern New England. Estuar Coast Shelf S 148:14-26. doi:10.1016/j.ecss.2014.06.007

Finkler NR, Tromboni F, Boëchat IG, Gücker B, Cunha DGF (2018) Nitrogen and phosphorus uptake dynamics in tropical cerrado woodland streams. Water 10:1080. doi:10.3390/w10081080

Fisheries Department of Agriculture Ministry of China 2015 China Fisheries Statistical Yearbook, China Agriculture Press, Beijing (in Chinese).

Glibert PM, Harrison J, Heil C, Seitzinger S (2006) Escalating worldwide use of urea-a global change contributing to coastal eutrophication. Biogeochemistry 77(3):441-463. doi:10.1007/s10533-005-3070-5

Gücker B, Pusch MT 2006 Regulation of nutrient uptake in eutrophic lowland streams. Limnol Oceanogr 51:1443-1453. doi:10.4319/lo.2006.51.3.1443

Guerrero-Galván SR, Páez-Osuna F, Ruiz-Fernández AC, Espinoza-Angulo R (1999) Seasonal variation in the water quality and chlorophyll $a$ of semi-intensive shrimp ponds in a subtropical environment. Hydrobiologia 391:33-45. doi:10.1023/A:1003590625379

Hall RJO, Tank JL (2003) Ecosystem metabolism controls nitrogen uptake in streams in Grand Teton National Park, Wyoming. Limnol Oceanogr 48:1120-1128. doi:10.4319/lo.2003.48.3.1120

Hargreaves J A (1998) Nitrogen biogeochemistry of aquaculture ponds. Aquaculture 166:181-212. doi: 10.1016/s0044-8486(98)00298-1

Holmer M, Thorsen SW, Carlsson MS, Kjerulf PJ (2015) Pelagic and benthic nutrient regeneration processes in Mussel Cultures (Mytilus edulis) in a Eutrophic coastal area (Skive Fjord, Denmark). Estuar Coast 38:1629-1641. doi:10.1007/s12237-014-9864-8 
House WA, Warwick MS (1999) Interactions of phosphorus with sediments in the River Swale, Yorkshire, UK. Hydrol Process $13: 1103-1115$. doi:10.1002/(SICI)1099-1085(199905)13:7<1103::AID-HYP792>3.0.CO;2-6

Huang SL, Wu M, Zang CJ, Du SL, Domagalski J, Gajewska M, Gao F, Lin C, Guo Y, Liu BY, Wang SM, Luo Y, Szymkiewicz A, Szymkiewicz R (2016) Dynamics of algae growth and nutrients in experimental enclosures culturing bighead carp and common carp: phosphorus dynamics. Int J Sediment Res 31:173-180. doi:10.1016/j.ijsrc.2016.01.003

Jiang DH, Lawrence AL, Neill WH, Gong H (2000) Effects of temperature and salinity on nitrogenous excretion by Litopenaeus vannamei juveniles. J Exp Mar Biol Ecol 253(2):193-209. doi: 10.1016/S0022-0981(00)00259-8

Jansen HM, Strand $\varnothing$, Verdegem M, Smaal A (2012) Accumulation, release and turnover of nutrients (C-N-P-Si) by the blue mussel Mytilus edulis under oligotrophic conditions. J. Exp. Mar Biol Ecol 416-417:185-195. doi:10.1016/j.jembe.2011.11.009

Jeffrey SW, Humphrey GF (1975) New spectrophotometric equations for determining chlorophylls $a, b, c_{1}$ and $c_{2}$ in higher plants, algae and natural phytoplankton. Biochemie und Physiologic der Pflanzen 167:191-194. doi:10.1016/S0015-3796(17)30778-3

Lacoste É, Gaertner-Mazouni N (2016) Nutrient regeneration in the water column and at the sediment-water interface in pearl oyster culture (Pinctada margaritifera) in a deep atoll lagoon (Ahe, French Polynesia). Estuar Coast Shelf S 182:304-309. doi:10.1016/j.ecss.2016.01.037

Lai SY 2014 The Ecological Aquaculture Technique of Prawn. China Agriculture Press, Beijing (in Chinese).

Li SQ, Lin XT, Li ZJ (2006) Feeding of effects on metabolism of white Pacific shrimp (Litopenaeus vannamei). J Trop Oceanogr 25(2):44-48 (in Chinese).

Liu SW, Hu ZQ, Wu S, Li SQ, Li ZF, Zou JW (2015) Methane and nitrous oxide emissions reduced following conversion of rice paddies to inland crab-fish aquaculture in southeast China. Environ Sci Technol 50(2):633-642. doi:10.1021/acs.est.5b04343

McCarthy MJ, Gardner WS, Lehmann MF, Guindon A, Bird DF. 2016. Benthic nitrogen regeneration, fixation, and denitrification in a temperate, eutrophic lake: Effects on the nitrogen budget and cyanobacteria blooms. Limnol Oceanog 61(4), 1406-1423. doi:10.1002/lno.10306

Meng J, Yu ZG, Yao QZ, Bianchi TS, Paytan A, Zhao B, Pan HH, Yao P (2015) Distribution, mixing behavior, and transformation of dissolved inorganic phosphorus and suspended particulate phosphorus along a salinity gradient in the Changjiang Estuary. Mar Chem 168:124-134. doi:10.1016/j.marchem.2014.09.016

Millero F, Huang F, Zhu X, Liu X, Zhang JZ (2001) Adsorption and desorption of phosphate on calcite and aragonite in seawater. Aquat. Geochem 7(1):33-56. doi:10.1023/A:1011344117092

Molnar N, Welsh DT, Marchand C, Deborde J, Meziane T (2013) Impacts of shrimp farm effluent on water quality, benthic metabolism and $\mathrm{N}$-dynamics in a mangrove forest (New Caledonia). Estuar Coast Shelf S 117:12-21. doi:10.1016/j.ecss.2012.07.012

Mook WT, Chakrabart MH, Aroua MK, Khan GMA, Ali BS, Islam MS, Abu Hassan MA (2012) Removal of total ammonia nitrogen (TAN), nitrate and total organic carbon (TOC) from aquaculture wastewater using electrochemical technology: a review. Desalination 285:1-13. doi:10.1016/j.desal.2011.09.029

Morrissey EM, Gillespie JL, Morina JC, Franklin RB (2014) Salinity affects microbial activity and soil organic matter content in tidal wetlands. Global Change Biol 20:1351-1362. doi:10.1111/gcb.12431. 
Neubauer SC 2012 Ecosystem responses of a tidal freshwater marsh experiencing saltwater intrusion and altered hydrology. Estuar Coast 36:491-607. doi:10.1007/s12237-011-9455-x

Neubauer SC, Franklin RB, Berrier DJ (2013) Saltwater intrusion into tidal freshwater marshes alters the biogeochemical processing of organic carbon. Biogeosciences 10:8171-8183. doi:10.5194/bgd-10-10685-2013

Páez-Osuna F, Guerrero-Galván SR, Ruiz-Fernández AC, Espinoza-Angulo R (1997) Fluxes and mass balances of nutrients in a semi-intensive shrimp farm in north-western Mexico. Mar Pollut Bull 34(5):290-297. doi:10.1016/S0025-326X(96)00133-6

Paerl HW, Fulton RS, Moisander PH, Dyble J (2001) Harmful freshwater algal blooms, with an emphasis on Cyanobacteria. The Sci World J 1:76-113. doi:10.1100/tsw.2001.16

Pinho L, Duarte CM, Marotta H, Enrich-Prast A (2016) Temperature dependence of the relationship between $p \mathrm{CO}_{2}$ and dissolved organic carbon in lakes. Biogeosciences 13:865-871. doi:10.5194/bg-13-865-2016

Porcal P, Dillon PJ, Molot LA (2015) Temperature dependence of photodegradation of dissolved organic matter to dissolved inorganic carbon and particulate organic carbon. PLoS One 10(6):e0128884. doi:10.1371/journal.pone.0128884

Reddy KR, Kadlec RH, Flaig E, Gale PM (1999) Phosphorus retention in streams and wetlands: A review. Crit Rev Environ Sci Technol 29:83-146. doi:10.1080/10643389991259182

Richard M, Archambault P, Thouzeau G, McKindsey CW, Desrosiers G 2007. Influence of suspended scallop cages and mussel lines on pelagic and benthic biogeochemical fluxes in Havre-aux-Maisons Lagoon, Îles-de-la-Madeleine (Quebec, Canada). Can J Fish Aquat Sci 64(11): doi:1491-1505.10.1139/f07-116

Roache MC, Bailey PC, Boon PI (2006) Effects of salinity on the decay of the freshwater macrophyte, Triglochin procerum. Aquat Bot 84:45-52. doi:10.1016/j.aquabot.2005.07.014

Silva KR, Wasielesky Jr. W, Abreu PC (2013) Nitrogen and phosphorus dynamics in the biofloc production of the Pacific white shrimp, Litopenaeus vannamei. J Word Aquacult Soc 44(1):30-41. doi:10.1111/jwas.12009

Simon M, Grossart H-P, Schweitzer B, Ploug H (2002) Microbial ecology of organic aggregates in aquatic ecosystems. Aquat Microb Ecol 28: 175-211.

Srisunont C, Babel S (2015) Uptake, release, and absorption of nutrients into the marine environment by the green mussel (Perna viridis). Mar Pollut Bull 97:285-293. doi:10.1016/j.marpolbul.2015.06.004

Taipale SJ, Sonninen E (2009) The influence of preservation method and time on the $\delta^{13} \mathrm{C}$ value of dissolved inorganic carbon in water samples, Rapid Commun. Mass Sp 23(16):2507-2510. doi: $10.1002 / \mathrm{rcm} .4072$

Tong C, Cadillo-Quiroz H, Zeng ZH, She CX, Yang P, Huang JF (2017) Changes of community structure and abundance of methanogens in soils along a freshwater-brackish water gradient in subtropical estuarine marshes. Geoderma 299:101-110. doi:10.1016/j.geoderma.2017.03.026

Tong C, Wang WQ, Zeng CS, Marrs R (2010) Methane emissions from a tidal marsh in the Min River estuary, southeast China. J Environ Sci Heal A 45:506-516.doi:10.1080/10934520903542261

Tong C, Wang WQ, Huang JF, Gauci V, Zhang LH, Zeng, CS (2012) Invasive alien plants increase $\mathrm{CH}_{4}$ emissions from a subtropical tidal estuarine wetland. Biogeochemistry 111:677-693. doi:10.1007/s10533-012-9712-5 
van Broekhoven W, Troost K, Jansen H, Smaal A (2014) Nutrient regeneration by mussel Mytilus edulis spat assemblages in a macrotidal system. J Sea Res 88:36-46. doi:10.1016/j.seares.2013.12.007

Verdegem MCJ, Bosma RH (2009) Water withdrawal for brackish and inland aquaculture, and options to produce more fish in ponds with present water use. Water Policy 11:52-68. doi:10.2166/wp.2009.003

Wang C, Lai DYF, Tong C, Wang WQ, Huang JF, Zeng CS (2015) Variations in temperature sensitivity $\left(Q_{10}\right)$ of $\mathrm{CH}_{4}$ emission from a subtropical estuarine marsh in southeast China. PLoS ONE 10(5): e0125227. doi:10.1371/journal.pone.0125227

Wang HT, Liao GS, D’Souza M, Yu XQ, Yang J, Yang XR, Zheng TL (2016) Temporal and spatial variations of greenhouse gas fluxes from a tidal mangrove wetland in Southeast China. Environ. Sci Pollut Res 23:1873-1885. doi:10.1007/s11356-015-5440-4

Wang XF, He YX, Yuan XZ, Chen H, Peng CH, Yue JS, Zhang QY, Diao YB, Liu SS (2017) Greenhouse gases concentrations and fluxes from subtropical small reservoirs in relation with watershed urbanization. Atmos Environ 154:225-235. doi:10.1016/j.atmosenv.2017.01.047

Weyhenmeyer GA, Kosten S, Wallin MB, Tranvik LJ, Jeppesen E, Roland F 2015 Significant fraction of $\mathrm{CO}_{2}$ emissions from boreal lakes derived from hydrologic inorganic carbon inputs. Nat Geosci 2015, 8(12):933-936. doi:10.1038/ngeo2582

Xiong YH, Wang F, Guo XT, Liu F, Dong SL (2017) Carbon dioxide and methane fluxes across the sediment-water interface in different grass carp Ctenopharyngodon idella polyculture models. Aquacult Environ Interact 9:45-56. doi:10.3354/aei00214.

Yang H 2014 China must continue the momentum of green law. Nature 509:535-535. doi:10.1038/509535a

Yang H, Andersen T, Dörsch P, Tominaga K, Thrane J-E, Hessen DO (2015) Greenhouse gas metabolism in Nordic boreal lakes. Biogeochemistry 126:211-225. doi:10.1007/s10533-015-0154-8

Yang H, Hang X, Thompson JR, Flower RJ (2015) Enforcement key to China's environment. Science 347:834-835. doi:10.1126/science.347.6224.834-d

Yang H, Xing Y, Xie P, Ni L, Rong K (2008) Carbon source/sink function of a subtropical, eutrophic lake determined from an overall mass balance and a gas exchange and carbon burial balance. Environ Pollut 151:559-568. doi:10.1016/j.envpol.2007.04.006

Yang P, Lai DYF, Jin B, Bastviken D, Tan LS, Tong C (2017) Dynamics of dissolved nutrients in the aquaculture shrimp ponds of the Min River estuary, China: Concentrations, fluxes and environmental loads. Sci Total Environ 603-604:256-267. doi:10.1016/j.scitotenv.2017.06.074

Yang P, Zhang YF, Lai DYF, Tan LS, Jin BS, Tong C (2018) Fluxes of carbon dioxide and methane across the water-atmosphere interface of aquaculture shrimp ponds in two subtropical estuaries: The effect of temperature, substrate, salinity and nitrate. Sci Total Environ 635:1025-1035. doi:10.1016/j.scitotenv.2018.04.102

Yang P, Lai DYF, Yang H, Tong C (2019) Carbon dioxide dynamics from sediment, sediment-water interface and overlying water in the aquaculture shrimp ponds in subtropical estuaries, southeast China. J Environ Manage 236:224-235. doi:10.1016/j.jenvman.2019.01.088 
Yao X, Zhang YL, Zhu GW, Qin BQ (2014) Different degradation mechanism of dissolved organic matter derived from phytoplankton and macrophytes in Lake Taihu, China. Acta Scientiae Circumstantiae 34(3): 688-694. doi: 10.13671/j.hjkxxb.2014.0120

Yao X, Zhang YL, Zhu GW, Qin BQ, Feng LQ, Cai LL, Gao G (2011) Resolving the variability of CDOM fluorescence to differentiate the sources and fate of DOM in Lake Taihu and its tributaries. Chemosphere 2011, 82(2):145-155. doi: 10.1016/j.chemosphere.2010.10.049

Zhang K, Tian XL, Dong SL, Feng J, He RP (2016) An experimental study on the budget of organic carbon in polyculture systems of swimming crab with white shrimp and short-necked clam. Aquaculture 451:58-64. doi:10.1016/j. aquaculture.2015.08.029

Zhang JZ, Huang XL (2011) Effect of temperature and salinity on phosphate sorption on marine sediments. Environ Sci Technol 45(16):6831-6837. doi:10.1021/es200867p

Zhang L, Wang L, Yin KD, Lü Y, Zhang DR, Yang YQ, Huang XP (2013) Pore water nutrient characteristics and the fluxes across the sediment in the Pearl River estuary and adjacent waters, China. Estuar Coast Shelf S 133:182-192. doi:10.1016/j.ecss.2013.08.028

Zhang M, Xie P, Xu J, Liu B, Yang H (2006) Spatiotemporal variations of internal P-loading and the related mechanisms in the large shallow Lake Chaohu. Science in China Series D: Earth Sciences 49:72-81. doi:10.1007/s11430-006-8107-7

Zhang YL, van Dijk M A, Liu ML, Zhu GW, Qin BQ (2009) The contribution of phytoplankton degradation to chromophoric dissolved organic matter (CDOM) in eutrophic shallow lakes: field and experimental evidence. Water Res 43(18):4685-4697.doi: 10.1016/j.watres.2009.07.024

Zhong DS, Wang F, Dong SL, Li L (2015) Impact of Litopenaeus vannamei bioturbation on nitrogen dynamics and benthic fluxes at the sediment-water interface in pond aquaculture. Aquacult Int 23(4):967-980. doi:10.1007/s10499-014-9855-6

Zhou XP, Chen NW, Yan ZH, Duan SW (2016) Warming increases nutrient mobilization and gaseous nitrogen removal from sediments across cascade reservoirs. Environ Poll 219:490-500. doi:10.1016/j.envpol.2016.05.060

Zhu AJ, Sun DY, Tan J, Huang JF, Luo M (2019) Parallel factor analysis of fluorescence excitation emission matrix spectroscopy of CDOM from the mid-culture period of shrimp ponds in a subtropical estuary. Environ Sci 40(1):164-171. doi: 10.13227/j.hjkx.201805235 


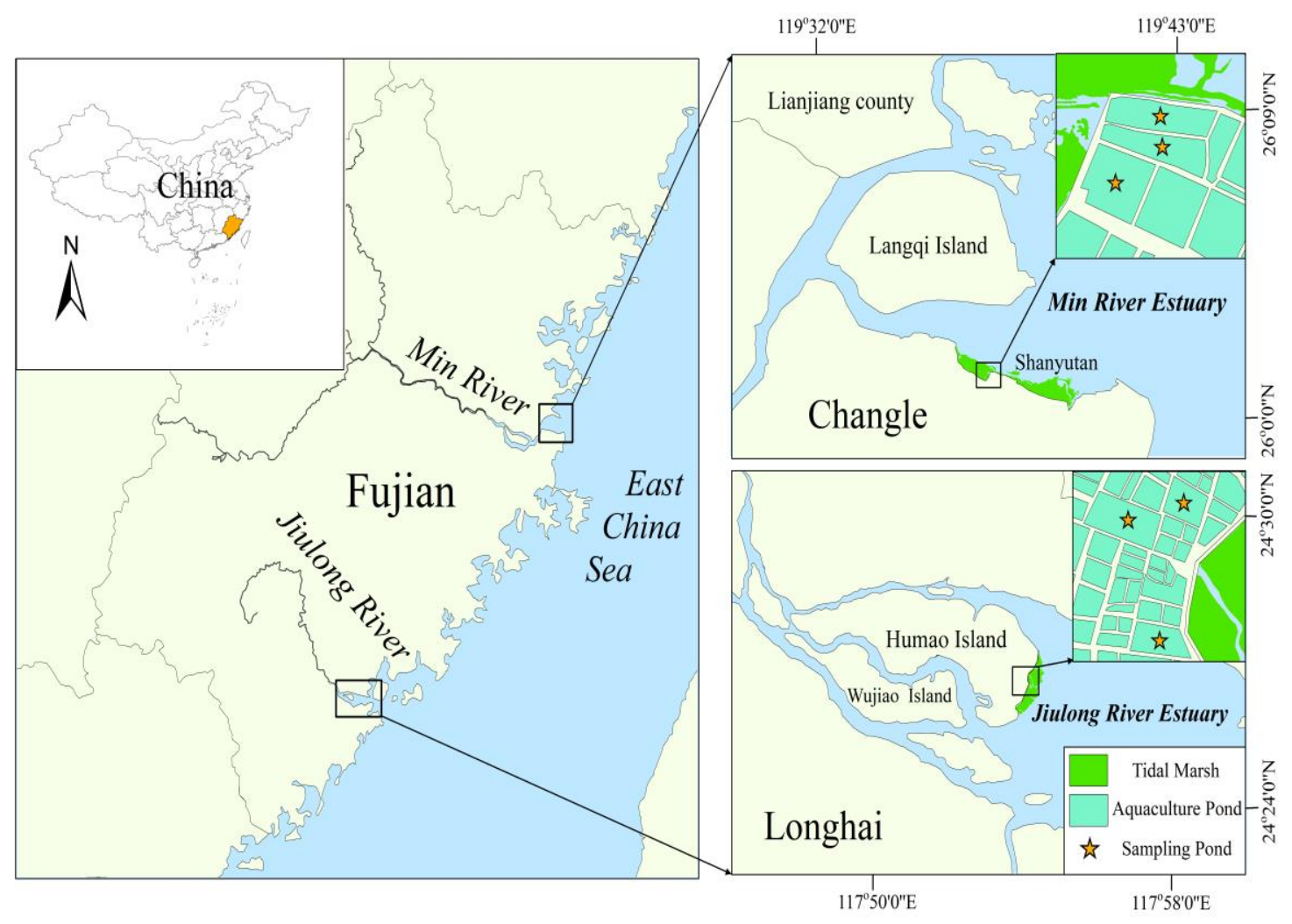

Fig. 1 Location of the study area and sampling sites in the Min River and Jiulong River estuaries in southeast China. 

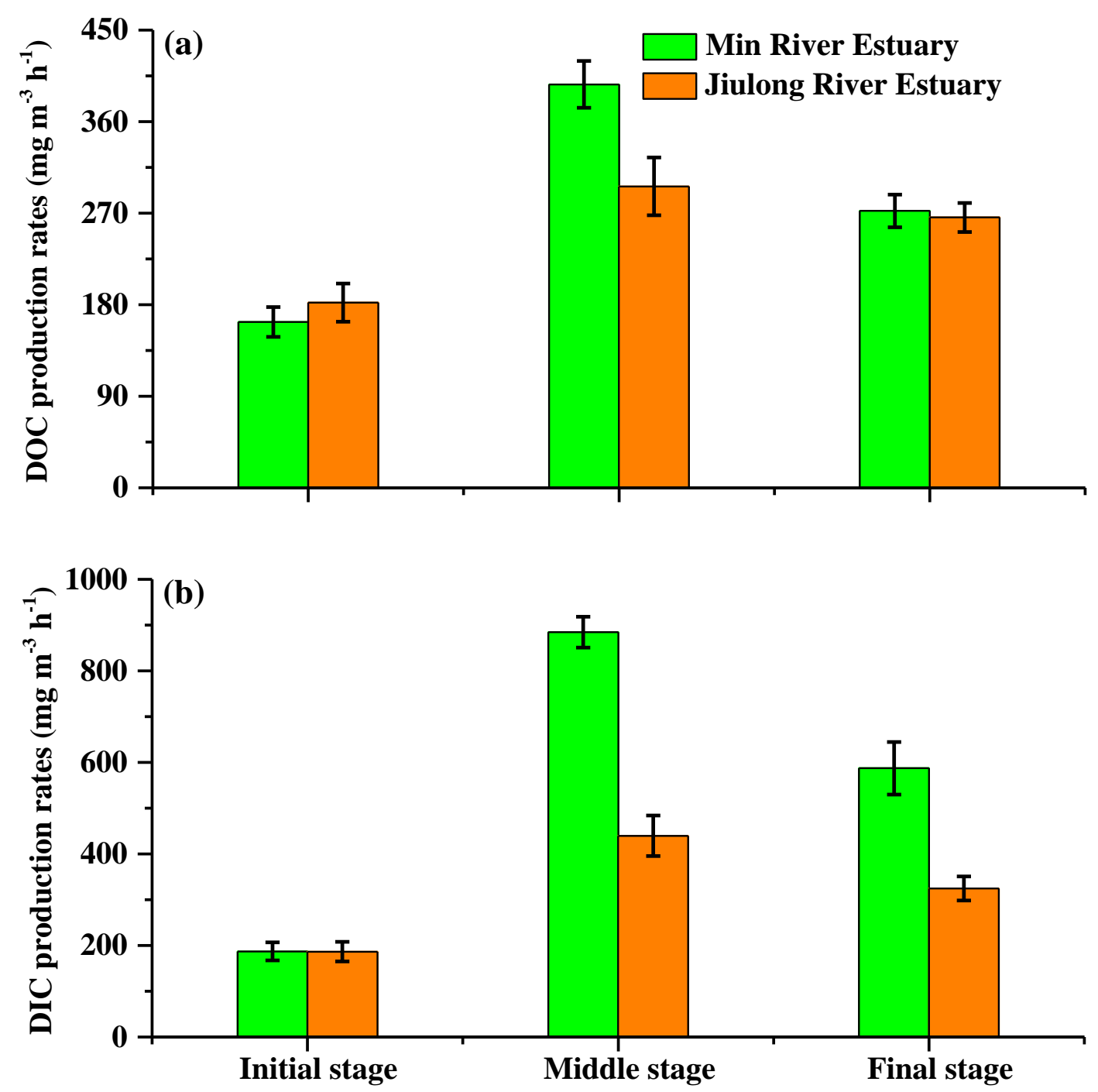

Fig. 2 Mean production rates of (a) dissolved organic carbon (DOC), and (b) dissolved inorganic carbon (DIC) in the overlying water (approximately $5-10 \mathrm{~cm}$ above the sediment) of shrimp ponds in the Min River Estuary (MRE) and Jiulong River Estuary (JRE) among the three aquaculture stages. The bars represent the mean $\pm \operatorname{SE}(n=9)$. 

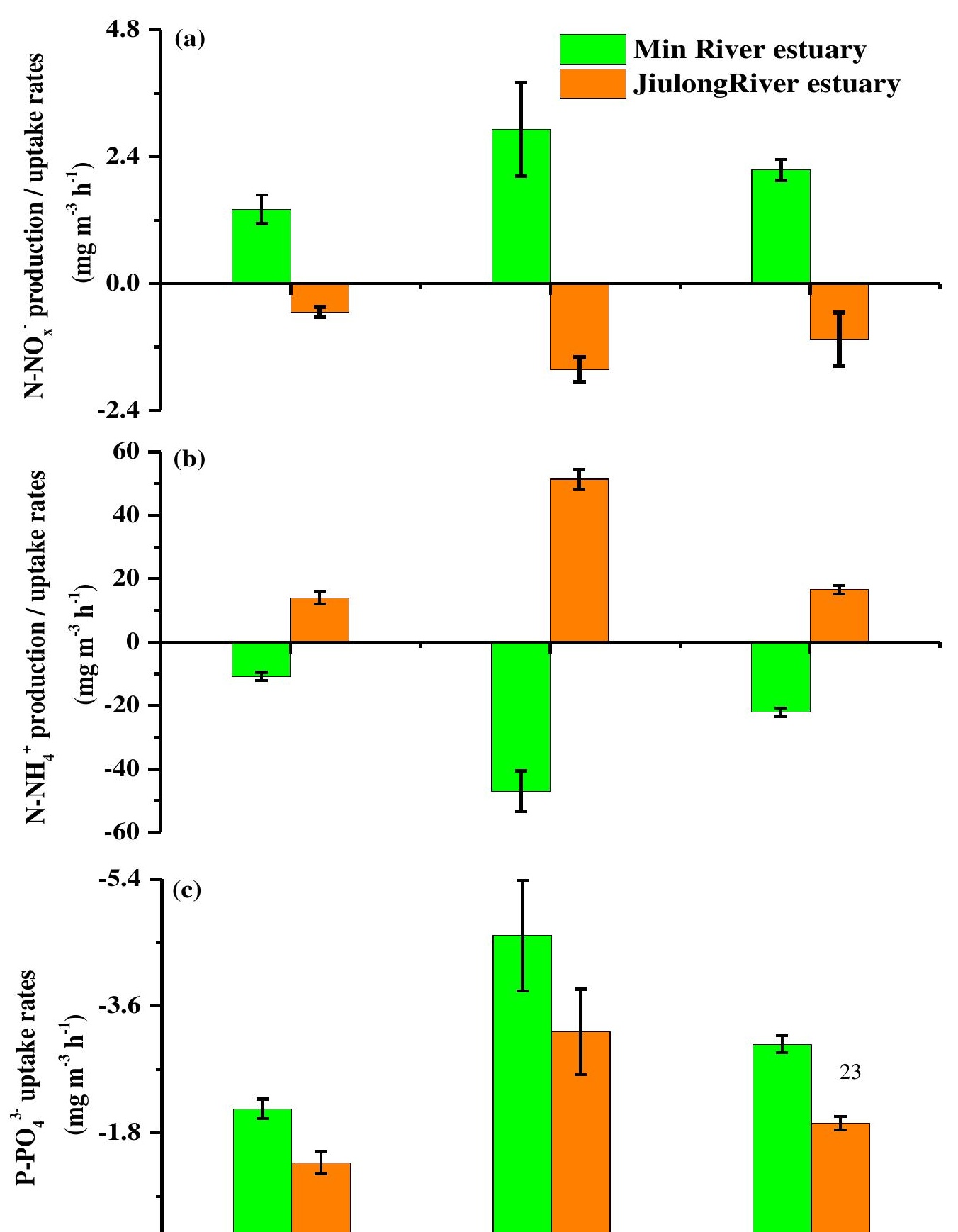
Fig. 3 Mean production rates of (a) N-NO${ }_{x}{ }^{-}$, and (b) N-NH${ }_{4}{ }^{+}$, and (c) mean uptake rate of $\mathrm{P}_{-} \mathrm{PO}_{4}{ }^{3-}$ in the overlying water of shrimp ponds in the Min River Estuary (MRE) and Jiulong River Estuary (JRE) among the three aquaculture stages. The bars represent the mean \pm SE $(n=9)$. 
Table 1 Physicochemical and biological properties in the overlying water of shrimp ponds in the Min River Estuary (MRE) and Jiulong River Estuary (JRE).

\begin{tabular}{|c|c|c|c|c|c|c|}
\hline \multirow{2}{*}{ Environmental Variables } & \multicolumn{3}{|c|}{ Min River Estuary } & \multicolumn{3}{|c|}{ Jiulong River Estuary } \\
\hline & Initial stage & Middle stage & Final stage & Initial stage & Middle stage & Final stage \\
\hline Water temperature $\left({ }^{\circ} \mathrm{C}\right)$ & $23.99 \pm 0.03$ & $30.66 \pm 0.12$ & $24.05 \pm 0.24$ & $26.34 \pm 0.12$ & $31.69 \pm 0.04$ & $27.88 \pm 0.06$ \\
\hline $\mathbf{p H}^{*}$ & $8.96 \pm 0.02$ & $8.63 \pm 0.07$ & $9.99 \pm 0.04$ & $9.21 \pm 0.07$ & $8.67 \pm 0.13$ & $9.48 \pm 0.08$ \\
\hline Dissolved oxygen $\left(\mathrm{mg} \mathrm{L}^{-1}\right)^{*}$ & $7.76 \pm 0.12$ & $11.01 \pm 0.95$ & $11.69 \pm 0.52$ & $8.19 \pm 0.19$ & $8.35 \pm 0.16$ & $9.94 \pm 0.37$ \\
\hline Salinity (\%o) & $3.27 \pm 0.01$ & $2.51 \pm 0.00$ & $1.91 \pm 0.00$ & $13.61 \pm 0.30$ & $7.39 \pm 0.20$ & $6.39 \pm 0.13$ \\
\hline Chlorophyll $a\left(\mu \mathrm{g} \mathrm{L}^{-1}\right)$ & $125.09 \pm 1.98$ & $248.21 \pm 2.72$ & $242.70 \pm 3.69$ & $29.31 \pm 1.09$ & $94.37 \pm 12.33$ & $72.09 \pm 5.88$ \\
\hline
\end{tabular}

* Data are after Yang et al. (2019) for reference and review only.

Table 2 Summary of two-way ANOVAs that examining the effect of aquaculture stages, sampling estuaries and their interactions on the DOC and DIC production rates in the overlying water of shrimp ponds.

\begin{tabular}{|c|c|c|c|c|c|c|c|c|c|c|}
\hline & \multicolumn{5}{|c|}{ DOC_prod rate } & \multicolumn{5}{|c|}{ DIC_prod rate } \\
\hline & $d f$ & Sum of squares & Mean square & $F$ values & $P$ values & $d f$ & Sum of squares & Mean square & $F$ values & $P$ values \\
\hline Stages & 2 & 24614.107 & 12307.054 & 38.545 & $<0.001$ & 2 & 184081.104 & 92040.552 & 86.141 & $<0.001$ \\
\hline Estuaries & 1 & 1036.150 & 1036.150 & 3.245 & $=0.078$ & 1 & 67703.708 & 67703.708 & 63.364 & $<0.001$ \\
\hline Stages $\times$ Estuaries & 2 & 3202.959 & 1601.480 & 5.016 & 0.011 & 2 & 40422.450 & 20211.225 & 18.916 & $<0.001$ \\
\hline Residuals & 48 & 15325.889 & 319.289 & & & 48 & & & & \\
\hline
\end{tabular}


Table 3 Pearson correlation coefficients for DOC, DIC production rates, and environmental variables of shrimp ponds in subtropical estuaries during the aquaculture period $^{\mathrm{a}}$.

\begin{tabular}{|c|c|c|c|c|c|c|}
\hline \multirow{2}{*}{ Environmental variables } & \multicolumn{3}{|c|}{ DOC_prod rate } & \multicolumn{3}{|c|}{ DIC prod rate } \\
\hline & MRE & JRE & Both estuaries & MRE & JRE & Both estuaries \\
\hline Water temperature & $0.881 * *$ & $0.834 * *$ & $0.698 * *$ & $0.821 * *$ & $0.931 * *$ & NS \\
\hline pH & NS & NS & NS & NS & NS & NS \\
\hline Dissolved oxygen & $0.708 * *$ & NS & $0.636 * *$ & $0.805 * *$ & NS & $0.769 * *$ \\
\hline Salinity & NS & $-0.868 * *$ & NS & $-0.621 *$ & $-0.808 * *$ & $-0.582 *$ \\
\hline Chlorophyll $a$ & $0.858 * *$ & $0.936 * *$ & $0.617 * *$ & $0.915 * *$ & $0.965 * *$ & $0.837 * *$ \\
\hline
\end{tabular}

${ }^{\text {a }} M R E$ and $J R E$ represent Min River Estuary and Jiulong River Estuary, respectively. * and ** indicate significance at the 0.05 and 0.01 levels, respectively. $n=27$ for environmental variables, DOC and DIC production rates of each estuary from the shrimp ponds. NS denotes not significant. 
Table 4 Multiple regression equations between environmental variables (e.g., water temperature, salinity, pH, dissolved oxygen, and chlorophyll a) and the production/uptake rates of dissolved carbon, nitrogen and phosphorus in shrimp ponds of subtropical estuaries during the aquaculture $\operatorname{period}^{\mathrm{a}}$.

\begin{tabular}{|c|c|c|c|c|c|}
\hline \multirow{3}{*}{ DOC production rates } & & Regression equations & $\boldsymbol{F}$ & $R^{2}$ & $p$ \\
\hline & MRE & $Y=335.776-5.112 x_{\mathrm{wT}}-171.191 x_{\mathrm{wS}}+1.560 x_{\mathrm{Chl}-a}$ & 42.468 & 0.847 & $<0.001$ \\
\hline & JRE & $Y=39.930+0.529 x \mathrm{Chl}-a$ & 44.164 & 0.639 & $<0.001$ \\
\hline \multirow{3}{*}{ DIC production rates } & Both estuaries & $Y=-66.577+5.967 x_{\mathrm{WT}}-3.131 x_{\mathrm{Ws}}$ & 26.893 & 0.513 & $<0.001$ \\
\hline & MRE & $Y=-421.585+29.568 x_{\mathrm{wT}}-0.916 x_{\mathrm{Chl}-a}$ & 118.250 & 0.908 & $<0.001$ \\
\hline & JRE & $Y=-1043.875+20.473 x_{\mathrm{WT}}+60.610 x_{\mathrm{pH}}$ & 35.927 & 0.750 & $<0.001$ \\
\hline \multirow{3}{*}{$\mathrm{N}-\mathrm{NO}_{\mathrm{x}}{ }^{-}$production/uptake rates } & Both estuaries & $Y=-315.470+14.420 x_{\mathrm{DO}}+13.169 x_{\mathrm{wT}}-8.924 x_{\mathrm{ws}}$ & 34.018 & 0.671 & $<0.001$ \\
\hline & MRE & NV & 1 & 1 & I \\
\hline & JRE & $Y=1.248-0.055 x \mathrm{wT}$ & 4.940 & 0.165 & $=0.036$ \\
\hline \multirow{3}{*}{$\mathrm{N}-\mathrm{NH}_{4}{ }^{+}$production/uptake rates } & Both estuaries & $Y=1.387-0.055 x_{\mathrm{WT}}$ & 24.038 & 0.591 & $<0.001$ \\
\hline & MRE & $Y=27.843+0.006 x_{\mathrm{Chl}-a}-0.085 x_{\mathrm{DO}}-0.047 x_{\mathrm{WT}}$ & 36.757 & 0.595 & $<0.001$ \\
\hline & JRE & $Y=0.351+1.684 x_{\mathrm{WT}}-4.429 x_{\mathrm{PH}}$ & 144.297 & 0.923 & $<0.001$ \\
\hline \multirow{4}{*}{$\mathrm{P}-\mathrm{PO}_{4}{ }^{3-}$ uptake rates } & Both estuaries & $Y=-12.919-0.082 x \mathrm{Chl}-a+0.880 x \mathrm{wT}$ & 36.436 & 0.588 & $<0.001$ \\
\hline & MRE & $Y=1.723-0.074 x_{\mathrm{WT}}-0.075 x_{\mathrm{DO}}$ & 10.080 & 0.457 & $<0.001$ \\
\hline & JRE & $Y=2.285-0.103 x_{\mathrm{WT}}$ & 13.974 & 0.359 & $=0.001$ \\
\hline & Both estuaries & $Y=1.225-0.003 x_{\text {Chl }-a}-0.061 x_{\mathrm{WT}}$ & 15.746 & 0.382 & $<0.001$ \\
\hline
\end{tabular}

${ }^{a}$ MRE and JRE represent Min River Estuary and Jiulong River Estuary, respectively. WT, WS, Chl- $a$, and DO represent water temperature, salinity, chlorophyll $a$, and dissolved oxygen,

respectively. $n=27$ for environmental variables, and dissolved carbon, nitrogen and phosphorus production/uptake rates in the shrimp ponds of each estuary. NV denotes no input variables in the equation.

Table 5 Summary of two-way ANOVAs that examining the effect of sampling stages, sampling estuaries and their interactions on the production and uptake of dissolved nitrogen and phosphorus in the overlying water of shrimp ponds. 


\begin{tabular}{|c|c|c|c|c|c|c|c|c|c|c|c|c|c|}
\hline & \multirow[t]{2}{*}{$d f$} & \multicolumn{4}{|c|}{ N-NO ${ }^{-}$production/uptake rates $^{\mathrm{a}}$} & \multicolumn{4}{|c|}{$\mathrm{N}-\mathrm{NH}_{4}{ }^{+}$production/uptake rates ${ }^{\mathrm{a}}$} & \multicolumn{4}{|c|}{$\mathrm{P}_{-} \mathrm{PO}_{4}{ }^{3-}$ uptake rates } \\
\hline & & Sum of squares & Mean square & $\begin{array}{l}F \\
\text { values }\end{array}$ & $\begin{array}{l}P \\
\text { values }\end{array}$ & Sum of squares & Mean square & F values & $\begin{array}{l}P \\
\text { values }\end{array}$ & Sum of squares & Mean square & $\begin{array}{l}F \\
\text { values }\end{array}$ & $\begin{array}{l}P \\
\text { values }\end{array}$ \\
\hline Stages & 2 & 0.037 & 0.019 & 0.114 & $=0.893$ & 23.602 & 11.801 & 1.457 & $=0.243$ & 3.907 & 1.953 & 13.739 & $<0.001$ \\
\hline Estuaries & 1 & 12.686 & 12.686 & 77.377 & $<0.001$ & 3538.142 & 3538.142 & 436.818 & $<0.001$ & 1.425 & 1.425 & 10.024 & $=0.003$ \\
\hline Stages $\times$ Estuaries & 2 & 1.374 & 0.687 & 4.190 & $=0.021$ & 1237.676 & 618.838 & 76.402 & $<0.001$ & 0.075 & 0.037 & 0.262 & $=0.771$ \\
\hline Residuals & 48 & 7.869 & 0.164 & & & 388.791 & 8.100 & & & 6.824 & 0.142 & & \\
\hline
\end{tabular}

${ }^{a} \mathrm{~N}-\mathrm{NO}_{\mathbf{x}}{ }^{-}$production and $\mathrm{N}-\mathrm{NH}_{4}{ }^{+}$uptake phenomenon occurred in MRE ponds, and $\mathrm{N}-\mathrm{NO}_{\mathrm{x}}{ }^{-}$uptake and $\mathrm{N}-\mathrm{NH}_{4}{ }^{+}$production phenomenon occurred in JRE ponds 
Table 6 Pearson correlation coefficients between nitrogen $\left(\mathrm{N}-\mathrm{NO}_{\mathrm{x}}{ }^{-}\right.$and $\left.\mathrm{N}-\mathrm{NH}_{4}{ }^{+}\right)$ production (or uptake) rates, phosphorus $\left(\mathrm{P}_{-} \mathrm{PO}_{4}{ }^{3-}\right)$ uptake rates, and environmental variables of shrimp ponds in subtropical estuaries during the aquaculture period ${ }^{\mathrm{a}}$.

\begin{tabular}{|c|c|c|c|c|c|c|}
\hline \multirow{2}{*}{ Environmental variables } & \multicolumn{3}{|c|}{ N-NOx ${ }^{-}$production/uptake rates ${ }^{b}$} & \multicolumn{3}{|c|}{$\mathrm{N}-\mathrm{NH}_{4}{ }^{+}$production/uptake rates ${ }^{\mathrm{b}}$} \\
\hline & MRE & JRE & Both estuaries & MRE & JRE & Both estuaries \\
\hline Water temperature & 0.781* & 0.711* & NS & $-0.947 * *$ & $0.972 * *$ & $0.864 * *$ \\
\hline pH & NS & NS & NS & NS & $-0.921 * *$ & $-0.591 * *$ \\
\hline Dissolved oxygen & NS & NS & $0.615^{* *}$ & NS & NS & NS \\
\hline Salinity & NS & NS & $-0.653 * *$ & NS & NS & NS \\
\hline Chlorophyll $a$ & 0.709* & $0.696 *$ & $0.811 * *$ & $-0.753 *$ & $0.795 *$ & NS \\
\hline
\end{tabular}

${ }^{a}$ MRE and JRE represent Min River Estuary and Jiulong River Estuary. * and ** indicate significance at the 0.05 and 0.01 levels. $n=27$ for environmental variables, nitrogen and phosphorus rates of each estuary from the shrimp ponds. NS denotes not significant. ${ }^{\mathbf{b}} \mathrm{N}-\mathrm{NO}_{\mathbf{x}}{ }^{-}$production and $\mathrm{N}-\mathrm{NH}_{4}{ }^{+}$uptake phenomenon occurred in MRE ponds, and $\mathrm{N}-\mathrm{NO}_{\mathrm{x}}{ }^{-}$uptake and $\mathrm{N}-\mathrm{NH}_{4}{ }^{+}$production phenomenon occurred in JRE ponds 